\title{
Abnormal High Density Lipoproteins in Cerebrotendinous Xanthomatosis
}

\author{
V. Shore, G. Salen, F. W. Cheng, T. Forte, S. Shefer, G. S. Tint, \\ and F. T. LINDGREN, Biomedical Sciences Division, Lawrence Livermore \\ Laboratory, University of California, Livermore, California 94550; \\ Department of Medicine, College of Medicine and Dentistry of New Jersey, \\ New Jersey Medical School, Newark, New Jersey 07103; Donner Laboratory, \\ Lawrence Berkeley Laboratory, University of California, \\ Berkeley, California 94720
}

A B S T RACT The plasma lipoprotein profiles and high density lipoproteins (HDL) were characterized in patients with the genetic disease cerebrotendinous xanthomatosis (CTX). Abnormalities in the HDL may contribute to their increased atherogenesis and excessive deposits of tissue sterols in the presence of low or low-normal concentrations of plasma cholesterol $(165 \pm 25 \mathrm{mg} / \mathrm{dl})$ and low density lipoproteins (LDL). The mean HDL-cholesterol concentration in the CTX plasmas was $14.5 \pm 3.2 \mathrm{mg} / \mathrm{dl}$, about one-third the normal value. The low HDL-cholesterol reflects a low concentration and an abnormal lipid composition of the plasma HDL. Relative to normal HDL, the cholesteryl esters are low, free cholesterol and phospholipids essentially normal, and triglycerides increased. The ratio of apoprotein (apo) to total cholesterol in the HDL of CTX was two to three times greater than normal. In the CTX HDL, the ratio of apoAI to apoAII was high, the proportion of apoC low, and a normally minor form of apoAI increased relative to other forms. The HDL in electron micrographs appeared normal morphologically and in particle size. The abnormalities in lipoprotein distribution profile and composition of the plasma HDL result from metabolic defects that are not understood but may be linked to the genetic defect in bile acid synthesis in CTX. As a consequence, it is probable that the normal functions of the HDL, possibly including modulation of LDL-cholesterol uptake and the removal of excess cholesterol from peripheral tissues, are perturbed significantly in this disease.

Received for publication 28 July 1980 and in revised form 7 July 1981.

\section{INTRODUCTION}

Cerebrotendinous xanthomatosis $(\mathrm{CTX})^{1}$ is a rare, inherited lipid-storage disease characterized clinically by progressive neurologic dysfunction, premature atherosclerosis, and cataracts (1). Large deposits of cholesterol and cholestanol are present in virtually every tissue, particularly the Achilles tendons, brain, and lungs. Cholestanol, the 5- $\alpha$-dihydro derivative of cholesterol, is enriched relative to cholesterol in all tissues (1-3). In contrast to type IIa hyperlipoproteinemia in which tendon xanthomas are common and plasma cholesterol levels exceed $300 \mathrm{mg} / \mathrm{dl}$, plasma cholesterol concentrations are low normal in CTX patients (1-3). We have recently presented evidence that the major biochemical defect in CTX is abnormal bile acid synthesis, specifically, impaired oxidation of the cholesterol side chain in the formation of cholic acid $(4,5)$.

The transport system for sterol influx and efflux of tissues comprise the plasma lipoproteins, including low density lipoproteins (LDL), levels of which are positively correlated with atherosclerosis, and high density lipoproteins, levels of which are inversely correlated (6). The HDL may have major roles in inhibiting uptake and accumulation of LDL-cholesterol (7-9) and in transporting cholesterol from peripheral tissues to liver for excretion (10). Hence, we examined the plasma lipoprotein profiles and the properties of the

\footnotetext{
${ }^{1}$ Abbreviations used in this paper: CTX, cerebrotendinous xanthomatosis; HDL, high density lipoproteins; LDL low density lipoproteins; IDL, intermediate density lipoproteins; VLDL, very low density lipoproteins; SDS, sodium dodecyl sulfate.
} 
HDL of CTX patients for abnormalities that might promote excessive deposition of sterols in their peripheral tissues.

\section{METHODS}

Clinical characteristics of CTX patients. Clinical descriptions of the nine CTX patients (five women and four men) are given in Table I. None was on medication or other treatment. Patients J.C., E.E., and E.S. were the subjects of previous metabolic studies $(1,4,5)$. The patients were compared with a control group of 10 normolipidemic subjects ( 3 women and $7 \mathrm{men}$ ) of an average age of $50 \mathrm{yr}$ (range: 20-65). Blood samples were taken at $\sim 8: 00$ a.m. after a fast of $12-14 \mathrm{~h}$, and EDTA was added as an anticoagulant. Plasma triglyceride levels were determined by a Technicon Auto Analyzer (Technicon Instruments Corp. Tarrytown, N. Y. [11]). Plasma cholesterol and HDL cholesterol (after removal of lipoproteins of lower density by preparative centrifugation) were determined colorimetrically by the cholesterol oxidase method of Allain et al. (12). Plasma cholestanol was measured in a separate aliquot according to the gas-liquid chromatographic method of Salen (1).

Isolation of lipoproteins. Plasma lipoproteins were isolated by preparative ultracentrifugation. For analytical ultracentrifugal analysis, the low and high density lipoproteins were isolated as described by Ewing et al. (13). The isolated HDL $(d=1.063-1.21 \mathrm{~g} / \mathrm{ml})$ were subfractionated into $\mathrm{HDL}_{2}(d=1.063-1.125 \mathrm{~g} / \mathrm{ml})$ and $\mathrm{HDL}_{3}(d=1.125-1.21$ $\mathrm{g} / \mathrm{ml}$ ) (14) or into narrower density ranges by density gradient centrifugation. In the latter, $2 \mathrm{ml}$ undialyzed HDL was layered atop $0.5 \mathrm{ml} 50 \%$ sucrose (wt:wt) in 9/16 $\times 31 / 2$-in. tubes followed by $7 \mathrm{ml}$ of a $d=1.110$ solution $(0.196 \mathrm{M} \mathrm{NaCl}$, $1.390 \mathrm{M} \mathrm{NaBr})$ and finally $3 \mathrm{ml}$ of a $d=1.080$ solution $(0.196 \mathrm{M}$ $\mathrm{NaCl}, 0.973 \mathrm{M} \mathrm{NaBr}$ ). The tubes were centrifuged in a Beckman SW 41 rotor (Beckman Instruments, Inc., Fullerton,

\section{TABLE I}

\section{Data on CTX Patients}

\begin{tabular}{|c|c|c|c|}
\hline Patient & Sex & Age & Clinical symptoms \\
\hline & & yr & \\
\hline W.H. & $\mathbf{M}$ & 59 & $\begin{array}{l}\text { Dementia, spinal cord paresis, Achilles } \\
\text { tendon xanthomas, xanthelasma }\end{array}$ \\
\hline J.C. & $\mathbf{M}$ & 44 & $\begin{array}{l}\text { Achilles tendon xanthomas, tuberous } \\
\text { xanthomas of forearm }\end{array}$ \\
\hline G.A. & $\mathbf{F}$ & 60 & $\begin{array}{l}\text { Dementia, cataracts, spinal cord } \\
\text { paresis, Achilles tendon xanthomas, } \\
\text { tuberous xanthomas dorsum of hand }\end{array}$ \\
\hline V.R. & $\mathbf{F}$ & 60 & $\begin{array}{l}\text { Achilles tendon xanthomas, spinal } \\
\text { cord paresis }\end{array}$ \\
\hline E.E. & $\mathbf{F}$ & 52 & $\begin{array}{l}\text { Achilles tendon xanthomas, spinal } \\
\text { cord paresis }\end{array}$ \\
\hline E.S. & $\mathbf{F}$ & 54 & $\begin{array}{l}\text { Achilles tendon xanthomas, spinal } \\
\text { cord paresis }\end{array}$ \\
\hline T.G. & $\mathbf{M}$ & 21 & Achilles tendon xanthomas \\
\hline N.P. & $\mathbf{F}$ & 23 & Cataracts, Achilles tendon xanthomas \\
\hline L.R. & $\mathbf{M}$ & 28 & Achilles tendon xanthomas \\
\hline
\end{tabular}

Calif.) for $65 \mathrm{~h}$ at $40,000 \mathrm{rpm}$ and $16^{\circ} \mathrm{C}$. Twelve $1-\mathrm{ml}$ fractions were pipetted sequentially down the tube. $\mathrm{HDL}_{2}(d=1.08-$ $1.125 \mathrm{~g} / \mathrm{ml})$ and $\mathrm{HDL}_{3}(d=1.125-1.21 \mathrm{~g} / \mathrm{ml})$ were also isolated after density adjustment with $\mathrm{NaCl}$ and $\mathrm{D}_{2} \mathrm{O}$ as described by Shore (15). All solutions contained 0.1 $\mathrm{mg}$ EDTA/ml.

The HDL were dialyzed against a cold solution containing 0.1 or $0.15 \mathrm{M} \mathrm{NaCl}, 0.0008 \mathrm{M}$ EDTA, and in some cases Tris buffer at $\mathrm{pH} 7.2$ before analyzing their lipid and protein moieties. Protein concentration was determined by the colorimetric method of Lowry et al. (16). Phospholipids were estimated from the phosphorus content, determined by a modified colorimetric method of Chen et al. (17), in which hydrolysis was performed as described by Nelson (18). Free and total cholesterol were quantitated by the method of Allain et al. (12), and triglyceride, by Worthington Biochemical Corp. Freehold, N. J. enzymatic method.

Analytical ultracentrifugation of serum lipoproteins. The concentrations of the serum lipoproteins and their distribution as a function of flotation rate $\left(S_{f}{ }^{0}\right.$ or $\left.F_{1.20}{ }^{\circ}\right)$ were determined by computerized analysis of data from the schlieren patterns of analytical ultracentrifuge runs at 52,640 rpm of the isolated LDL (LDL, IDL, and VLDL) in a baseline solution of density $1.063 \mathrm{~g} / \mathrm{ml}$ and the isolated HDL in a solution of density $1.20 \mathrm{~g} / \mathrm{ml}(13,19)$. The flotation rates, determined by an " $\eta \mathrm{F}^{0}$ vs. $\rho$ " technique (19), are expressed in Svedbergs $\left(10^{-13} \mathrm{~cm} \cdot \mathrm{S}^{-1} \cdot \mathrm{dyn}^{-1} \cdot \mathrm{g}^{-1}\right)$ and are corrected for concentration dependence and to standard conditions $\left(\mathrm{T}=26^{\circ} \mathrm{C}\right)$. The apparently bimodal schlieren pattern for HDL is analyzed for concentrations of subfractions, the $\mathrm{HDL}_{2}$ and $\mathrm{HDL}_{3}(19)$. The $\mathrm{HDL}_{2}\left(\mathrm{~F}_{1.20}{ }^{\circ}=3.5-9.0\right)$ and $\mathrm{HDL}_{3}$ $\left(F_{1.20}{ }^{\circ}=0-3.5\right)$ correspond closely but not exactly to the subfractions defined, as is generally the case, in terms of the density intervals used in their isolation by preparative ultracentrifugation (20).

Electron microscopy of isolated $\mathrm{HDL}_{2}$ and $\mathrm{HDL}_{3}$. After dialysis against $0.13 \mathrm{M}$ ammonium acetate buffer, $\mathrm{pH} 7.4$, containing $345 \mu \mathrm{M}$ EDTA and $124 \mu \mathrm{M}$ Merthiolate, the lipoproteins were negatively stained with $2 \%$ sodium phosphotungstate, $\mathrm{pH} 7.4$ (21). Diameters of 100-200 free standing particles were obtained from each fraction by means of a computerized program using a sonic digitizer (Graf-Pen of Science Accessories Corporation, Southport, Conn.) which records X-Y coordinates and translates them into particle diameters. The precision of the method is $5-10 \%$. Values from electron microscopy for particle diameters are $\sim 10 \%$ higher than those calculated from analytical ultracentrifugal data and very similar to those from gradient gel electrophoresis (20). In the latter two methods, the lipoproteins were assumed to be Stokes' spheres. The electron microscopic method gives information on particle shape, morphology, and heterogeneity in both size and shape as well as the average particle size.

Lipid analysis. Total lipids of isolated $\mathrm{HDL}_{3}$ were determined gravimetrically after extraction into 3:2 and 3:1 (vol/vol) mixtures of chloroform and methanol. Phospholipid content of the lipids was estimated from the phosphorus content (17). The major classes of lipids (phospholipids, cholesterol, triglycerides, and cholesteryl esters) were separated and quantitated by thin-layer chromatography combined with flame ionization detection (22). The lipids were also separated as described by Nelson (18) by onedimensional, thin-layer chromatography on a Pyrex plate coated with silica gel. The solvent was petroleum ether/ diethyl ether/acetic acid (85:15:2 vol/vol). Cholesterol and the individual cholesteryl esters were quantitated by a highpressure liquid-chromatographic procedure similar to that of Duncan et al. (23). A Waters $\mu$ Bondapak $\mathrm{C}_{18}$ column (0.39 
$\times 30 \mathrm{~cm}$ ) was used isocratically with a solvent of isopropyl alcohol/acetonitrile $(25: 75 \mathrm{vol} / \mathrm{vol})$ at a flow rate of $1 \mathrm{ml} / \mathrm{min}$.

Amino acid analysis. The apolipoproteins $(\sim 50-150 \mu \mathrm{g})$ were hydrolyzed in vacuo for $40 \mathrm{~h}$ at $110^{\circ} \mathrm{C}$ with $0.25 \mathrm{ml}$ of $4 \mathrm{~N}$ methanesulfonic acid containing $0.2 \% \quad 3$-(2-aminoethyl) indole. Amino acids were analyzed by the procedure of Liu and Chang (24).

Polyacrylamide gel electrophoresis. Electrophoresis of delipidated HDL apolipoproteins ( $30 \mu \mathrm{g}$ protein/sample) was carried out in the presence of sodium dodecyl sulfate (SDS) in $4 \%$ and $10 \%$ gels $(25)$. Standards of pure apoAI $(15,18$, and $21 \mu \mathrm{g})$ and apoAII $(6,8$, and $10 \mu \mathrm{g})$ were run in $10 \%$ gels. After electrophoresis, the gels were fixed, stained, and then destained as described previously. (25). The gels were photographed with Polaroid film (Polaroid Corp., Cambridge, Mass.) and scanned in a Gilford recording spectrophotometer (Gilford Instrument Laboratories Inc., Oberlin, Ohio), which was equipped with a linear transport system and attached to a computing integrator. This electrophoretic system separated apoB, apoD, apoE, apoAI, apoAII, apoCIII, apoCII, and apoCI and gave information on the relative amounts of these apolipoproteins in CTX HDL as compared with normal HDL.

Polyacrylamide gel isoelectric focusing. The apolipoproteins of $\mathrm{HDL}(100 \mu \mathrm{g} / \mathrm{sample})$ in $0.05 \mathrm{M} \mathrm{NaCl}$ were separated in the pH ranges 4-6 and 4-8 and stained with Coomassie Blue R-250 (25). Gels were photographed and scanned by a densitometer as described above for SDS gels. This method does not detect apoB, but it resolves the variant forms of the other apolipoproteins.

\section{RESULTS}

Plasma lipids and HDL-cholesterol. Plasma triglyceride, cholesterol, cholestanol, and HDL-cholesterol concentrations are listed in Table II. All these CTX subjects had low to normal levels of plasma cholesterol and elevated cholestanol concentrations $(2.9 \pm 0.9$ vs. $0.6 \pm 0.2 \mathrm{mg} / \mathrm{dl}$ ) as compared with 10 normolipidemic subjects who served as controls. The relative abundance of cholestanol in the HDL sterols was comparable to that in the plasma sterols (26). The proportions of cholestanol in esterified form in plasma and isolated HDL are similar to the proportions of esterified cholesterol to total cholesterol in normal and CTX subjects, as expected from previous measurements of the rates of esterification of both sterols in two of our CTX patients and a normal subject (26). The combination of the clinical findings (Table I) with the plasmasterol measurements established the diagnosis of cerebrotendinous xanthomatosis (CTX). In these subjects, plasma HDL-cholesterol levels were markedly lower than in the control subjects $(14.5 \pm 3.2 \mathrm{mg} / \mathrm{dl}$ vs. $48.0 \pm 9.0 \mathrm{mg} / \mathrm{dl}$ ). Furthermore, the ratio of total plasma cholesterol to HDL-cholesterol was substantially higher in the CTX subjects than in the control groups (11.4 vs. 4.8). Thus, the HDL-cholesterol is reduced out of proportion to the total plasma cholesterol, which is also low in this disease. Fasting triglyceride levels in the CTX and control subjects were similar, although elevated values were detected in one CTX subject (W.H.).

The total protein and cholesterol concentrations of the isolated $\mathrm{HDL}_{2}$ and $\mathrm{HDL}_{3}$ preparations are given in Table III. In the $\mathrm{HDL}_{2}$ and $\mathrm{HDL}_{3}$ of CTX patients, the protein to cholesterol ratios were two to three times higher than in normal HDL. Thus, the low concentration of HDL-cholesterol in the plasma of CTX patients (Table II) results in part from the abnormal composition of the HDL, indicated also by the results of lipid analyses described in a later section.

Plasma lipoprotein profiles. Plasma lipoproteins of seven CTX individuals (three males and four females) were analyzed by analytical ultracentrifugation. Samples from two of these (W.H., male and G.A., female) were examined twice at intervals of 1.9 and $2.5 \mathrm{yr}$, respectively. Fig. 1 compares the lipoprotein profile of

TABLE II

Plasma Triglyceride, Cholesterol, Cholestanol, and HDL-Cholesterol Levels in CTX Patients and Normal Subjects*

\begin{tabular}{lccccr}
\hline \multicolumn{1}{c}{ Group } & Triglyceride & Cholesterol & Cholestanol & HDL-Cholesterol & $\begin{array}{r}\text { Total cholesterol } \\
\text { HDL cholesterol }\end{array}$ \\
\hline Normolipidemic subjects $¥$ & $115 \pm 33$ & $230 \pm 25$ & $0.6 \pm 0.015$ & $48.0 \pm 9.0$ & 4.8 \\
Patients & & & & & \\
W.H. & 273 & 149 & 2.1 & 15.9 & 9.4 \\
J.C. & 115 & 151 & 2.1 & 12.6 & 12.0 \\
G.A. & 122 & 201 & 3.2 & 15.0 & 13.4 \\
V.R. & 105 & 185 & 4.4 & 16.1 & 11.5 \\
T.G. & 61 & 149 & 3.0 & 15.7 & 9.5 \\
N.P. & 81 & 197 & 2.0 & 9.9 & 19.9 \\
E.E. & 116 & 136 & 3.0 & 11.0 & 12.4 \\
E.S. & 111 & 154 & 3.7 & 20.0 & 7.7 \\
Mean \pm SD & $123 \pm 64$ & $165 \pm 25$ & $2.9 \pm 0.9$ & $14.5 \pm 3.2$ & 11.4 \\
\hline
\end{tabular}

* Concentrations in milligrams per deciliter.

$\$$ Mean \pm SD of seven male and three female subjects. 
TABLE III

Protein and Cholesterol Concentrations* in HDL Fractions from

CTX Patients and Normolipidemic Subjects

\begin{tabular}{|c|c|c|c|c|c|c|}
\hline & \multicolumn{3}{|c|}{$\mathrm{HDL}_{2}$} & \multicolumn{3}{|c|}{$\mathrm{HDL}_{3}$} \\
\hline & Protein $(\mathbf{P})$ & Cholesterol (C) & P/C & Protein $(\mathrm{P})$ & Cholesterol (C) & P/C \\
\hline Normolipidemic subjects & $49.4 \pm 4.8 \ddagger$ & $17.6 \pm 2.0 \ddagger$ & 2.8 & $65.6 \pm 4.3 \ddagger$ & $24.8 \pm 1.2 \ddagger$ & 2.6 \\
\hline \multicolumn{7}{|l|}{ Patients } \\
\hline W.H. & 31.9 & 6.0 & 5.3 & 59.6 & 9.9 & 6.0 \\
\hline J.C. & 59.0 & 7.1 & 8.3 & 89.4 & 5.5 & 16.3 \\
\hline G.A. & 36.0 & 7.9 & 4.6 & 42.4 & 7.1 & 6.0 \\
\hline V.R. & 41.4 & 7.3 & 5.7 & 58.6 & 8.8 & 6.7 \\
\hline T.G. & 39.8 & 7.3 & 5.5 & 51.2 & 8.4 & 6.1 \\
\hline N.P. & 36.8 & 4.0 & 9.2 & 55.2 & 5.9 & 9.4 \\
\hline Mean $\pm S D$ & $40.8 \pm 9.5$ & $6.6 \pm 1.4$ & 6.2 & $59.4 \pm 16.0$ & $7.6 \pm 1.7$ & 7.8 \\
\hline
\end{tabular}

* Concentrations in milligrams per deciliter.

$\$$ Mean \pm SD of seven male and three female subjects.

$\mathrm{P} / \mathrm{C}$ in the normolipidemic female and male subjects was identical. Cholestanol accompanied cholesterol in the same proportion in each subfraction as in total plasma and HDL.

a normal, age-matched male with that of W.H. at the time the initial sample of Table II was taken and almost $2 \mathrm{yr}$ later, before initiation of treatment. At the latter time, W.H.'s plasma triglycerides and cholesterol were $125 \mathrm{mg} / \mathrm{dl}$ and $104 \mathrm{mg} / \mathrm{dl}$, respectively, and his disease had progressed. The plasma levels of LDL and HDL, which increase gradually with age in normal subjects
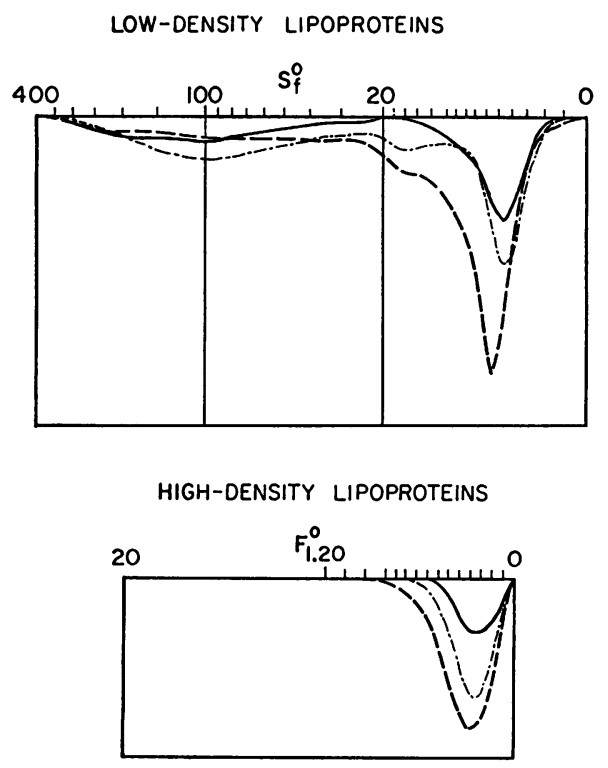

FIGURE 1 Serum lipoprotein profiles of CTX patient W. $\mathbf{H}$. initially ( --$)$ and almost 2 yr later $(-)$ and a normal, agematched male (- - ) from analytical ultracentrifugal analysis. Patterns are computer-reconstructed diagrams of the schlieren patterns indicating the distribution of lipoproteins as a function of flotation rate $\left(\mathrm{S}_{\mathrm{f}}{ }^{0}\right.$ or $\left.\mathrm{F}_{1.20}{ }^{\circ}\right)$. Peak area is proportional to concentration.
(27), declined significantly in W.H. (Fig. 1) and to a lesser extent in G.A. over the period of study. However, the plasma lipoprotein levels of L.R., a relatively young patient with a plasma cholestanol level of 1.9 $\mathrm{mg} / \mathrm{dl}$ and no apparent neurological disease, were also below those of age- and sex-matched controls and close to the average for male CTX patients. Table IV compares the average plasma lipoprotein concentrations determined by analytical ultracentrifugation for the male and female CTX patients and normal age- and sex-matched controls. Our control values are comparable to those obtained by an analytical ultracentrifugation study of 160 normal adults, 20 from each decade and sex (27). Values in Table IV from the latter study of normal subjects in different age groups were averaged to match the age distribution of the CTX patients. The normal $\mathrm{HDL}_{2}$ and $\mathrm{HDL}_{3}$ levels in milligrams per deciliter (not reported for the Modesto populations (27)) of our controls were similar to those reported previously (28) for 35-50-yr-old subjects: $172 \pm 81$ and $264 \pm 59$, respectively, for 16 normal females and $53 \pm 48$ and $222 \pm 31$, respectively, for 16 normal males. The LDL levels of the CTX patients were considerably below average except in G.A. The levels of $\mathrm{HDL}_{2}$ and total $\mathrm{HDL}$ were below average in two of the male CTX patients and normal ( 79 and 287 $\mathrm{mg} / \mathrm{dl}$, respectively) in J.C. In the female patients, the $\mathrm{HDL}_{2}$ levels were low $(23-84 \mathrm{mg} / \mathrm{dl}$ vs. $195 \mathrm{mg} / \mathrm{dl}$ for normal) in all and the $\mathrm{HDL}_{3}$ levels were low or low normal in three and high $(312 \mathrm{mg} / \mathrm{dl})$ in E.S. Since the peak $F_{1.20}{ }^{0}$ rates $(1.7-1.8)$ of the CTX $\mathrm{HDL}_{3}$ were in the normal range and the lipoprotein size and shape appeared normal (see below), analysis of the schlieren peak for $\mathrm{HDL}_{2}$ and $\mathrm{HDL}_{3}$ seems valid. The ratio of $\mathrm{LDL}$ to HDL (wt:wt) varied considerably in both male pa- 
TABLE IV

Plasma Lipoprotein Concentrations* of CTX Patients and Normal Controls

\begin{tabular}{|c|c|c|c|c|c|c|c|c|c|}
\hline \multirow[b]{3}{*}{ Subjects } & \multicolumn{9}{|c|}{ Lipoprotein fraction } \\
\hline & \multicolumn{3}{|c|}{ VLDL } & \multicolumn{3}{|c|}{ LDL } & \multicolumn{3}{|c|}{ HDL } \\
\hline & $S_{t} 100-400$ & $S_{1} 20-100$ & S, 20-400 & $S_{1} 12-20$ & $S_{t} 0-12$ & $S_{t} 0-20$ & $\mathrm{HDL}_{2}$ & $\mathrm{HDL}_{3}$ & HDL \\
\hline \multicolumn{10}{|l|}{ Male } \\
\hline $\begin{array}{l}\text { CTX }(n=3) \\
\text { Normal } \\
\text { Normal }\end{array}$ & $\begin{array}{c}62 \pm 36 \\
59\end{array}$ & $\begin{array}{c}96 \pm 43 \\
117\end{array}$ & $\begin{array}{c}158 \pm 73 \\
176 \\
102 \pm 68\end{array}$ & $\begin{array}{c}18 \pm 18 \\
77\end{array}$ & $\begin{array}{c}210 \pm 32 \\
412\end{array}$ & $\begin{array}{c}228 \pm 48 \\
489 \\
402 \pm 85\end{array}$ & $\begin{array}{c}29 \pm 34 \\
36\end{array}$ & $\begin{array}{c}160 \pm 60 \\
236\end{array}$ & $\begin{array}{c}187 \pm 77 \\
272 \\
266 \pm 73\end{array}$ \\
\hline \multicolumn{10}{|l|}{ Female } \\
\hline $\begin{array}{l}\text { CTX }(n=4) \\
\text { Normal } \\
\text { Normal } \ddagger\end{array}$ & $33 \pm 15$ & $\begin{array}{c}84 \pm 22 \\
7\end{array}$ & $\begin{array}{c}117 \pm 36 \\
7 \\
114 \pm 110\end{array}$ & $\begin{array}{c}23 \pm 16 \\
43\end{array}$ & $\begin{array}{c}206 \pm 39 \\
408\end{array}$ & $\begin{array}{c}229 \pm 44 \\
451 \\
398 \pm 100\end{array}$ & $\begin{array}{c}66 \pm 30 \\
195\end{array}$ & $\begin{array}{c}206 \pm 55 \\
237\end{array}$ & $\begin{array}{c}272 \pm 68 \\
432 \\
408 \pm 96\end{array}$ \\
\hline
\end{tabular}

* Concentrations in milligrams per deciliter $\pm \mathrm{SD}$.

† From Lindgren et al. (27).

tients (0.9-2.2 vs. $1.5-1.8$ for the normal averages) and female patients $(0.5-1.5$ vs. $0.7-1.0$ for normal), although the ratio of LDL-cholesterol to HDL-cholesterol was well above normal in all CTX subjects (Table II). The HDL concentrations are considerably higher than one might assume from the plasma HDL-cholesterol values (Table II). The latter values reflect, in addition to low HDL concentrations in CTX plasma (Table IV), an abnormal composition (Table III).

Morphology and particle size of CTX HDL. The $\mathrm{HDL}_{2}$ and $\mathrm{HDL}_{3}$ fractions from CTX patients (Fig. 2) were morphologically indistinguishable from those of normal subjects and consisted primarily of spherical particles. In the $\mathrm{HDL}_{2}, 1-2 \%$ of the total particles are larger (22-24 $\mathrm{nm}$ in Diam) than HDL and probably represent contaminating $\mathrm{LDL}$ or $\mathrm{HDL}_{\mathrm{c}}$. The large particles frequently are seen as a minor species in normal $\mathrm{HDL}_{2}$ isolated by conventional preparative ultracentrifugation. The diameter of $\mathrm{HDL}_{2}$ from a representative patient $W . H$. was $11.4 \pm 1.3 \mathrm{~nm}$, which is very similar to that $(11.5 \pm 1.8 \mathrm{~nm})$ from the age-matched, normal male. The $\mathrm{HDL}_{3}$ diameters in both these subjects were also similar, $9.7 \pm 1.0 \mathrm{~nm}$ for the former and $9.2 \pm 1.6 \mathrm{~nm}$ for the latter. The abnormal composition of HDL in CTX patients does not seem to perturb the lipoprotein morphology, at least within the limits of detection by electron microscopy.

Lipid composition of the HDL of CTX patients.
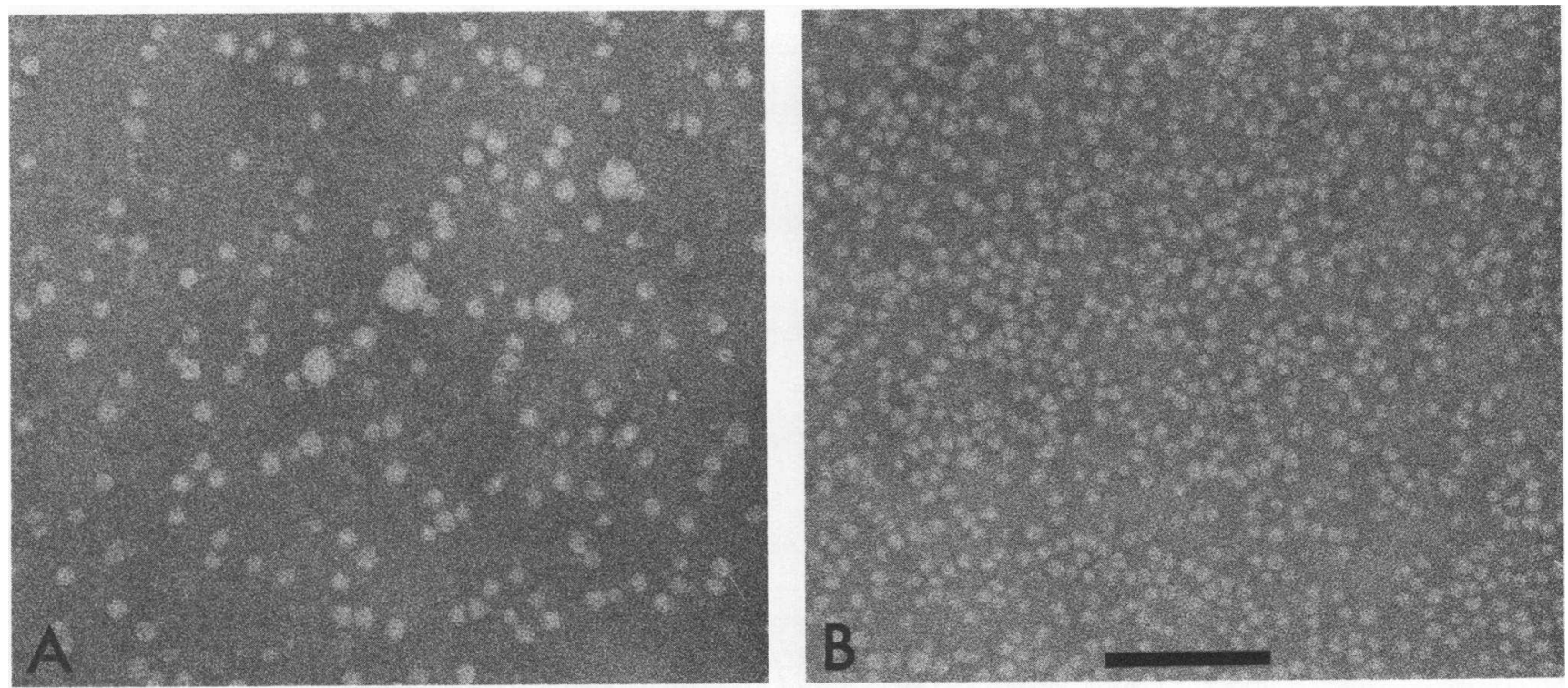

FIGURE 2 Electron micrographs of negatively stained $\mathrm{HDL}_{2}(\mathrm{~A})$ and $\mathrm{HDL}_{3}$ (B) from CTX patient W.H. The bar marker represents $100 \mathrm{~nm}$ and applies to both micrographs. 
The $\mathrm{HDL}_{2}$ and $\mathrm{HDL}_{3}$ of $4 \mathrm{CTX}$ patients ( 1 female and 3 males) and 10 normal subjects were analyzed quantitatively by enzymatic assays and thin-layer chromatography for unesterified cholesterol, esterified cholesterol, and triglycerides and colorimetrically for phospholipid and protein. The extracted $\mathrm{HDL}_{3}$ lipids of one CTX patient (W.H.) and one normal control were also examined quantitatively by the other procedures described in Methods for unesterified cholesterol, cholesteryl esters, total triglycerides, and phospholipids. The extracted lipid moiety comprised a normal fraction, i.e., 45 to $48 \%$ by weight, of CTX HDL 3 . The lipid compositions are given in Table V. The lipid data confirm the data of Table III, which shows a high ratio of protein to cholesterol in the HDL of all CTX subjects, and indicate a specific deficit in esterified cholesterol. The percentage of total phospholipids was essentially normal and the amount of triglycerides was about three times normal. Analysis by high-pressure liquid chromatography of the $\mathrm{HDL}_{3}$ lipids confirmed the results on the content of free cholesterol and cholesteryl esters and showed that cholesteryl linoleate accounts for most of the deficit in cholesteryl esters (Table V). Results of our lipid analyses of normal $\mathrm{HDL}_{3}$ are similar to values found in the literature (Table V). Since the size and density of CTX HDL are near normal, the deficit in cholesteryl esters must be compensated nearly quantitatively by triglycerides, as indicated by the data on percent composition of the lipid moiety. Since the molecular weights and partial specific volumes $(1.01 \mathrm{ml} / \mathrm{g})$ of cholesteryl esters are somewhat lower than those of triglycerides $(\bar{v}=1.09$ $\mathrm{ml} / \mathrm{g}$ ), the replacement probably is stoichiometrically $<1$ mol triglyceride for $1 \mathrm{~mol}$ cholesteryl ester.

Apolipoproteins of the $H D L_{2}$ and $H D L_{3}$. The apolipoproteins of six CTX patients were analyzed by SDS-polyacrylamide gel electrophoresis and polyacrylamide gel isoelectric focusing. During the period of study at least 20 normal HDL were examined. The SDS-gel (10\% acrylamide) patterns of CTX apo$\mathrm{HDL}_{2}$ (Fig. 3) and apoHDL $\mathrm{H}_{3}$ showed little if any apoD and apoE, a higher than normal ratio of apoAI to apoAII, and generally low apoC. ApoD and apoE were concentrated mainly in the $d=1.18 \mathrm{~g} / \mathrm{ml}$ subfraction, with lesser amounts in the adjacent fractions of $d=1.15$ and $1.21 \mathrm{~g} / \mathrm{ml}$, of all subjects after the HDL of patients G.A., W.H., and E.S. and 12 normal subjects were separated by density gradient ultracentrifugation into 12 subfractions from $d=1.067$ to $1.21 \mathrm{~g} / \mathrm{ml}$. There was no indication of abnormal amounts of apoD and apoE in the CTX HDL, but the possibility of preferential dissociation of apolipoproteins from the abnormal HDL during isolation from plasma was not investigated. For CTX $\mathrm{HDL}_{3}$, the ratio of peak areas of apoAI to apoAII in SDS gels were in the range 4.5-6.1, which according to the standard apoAI and apoAII gels corresponded to weight ratios of 3.6-4.8. By comparison, the normal ratio was 1.9 to 2.9. Since the concentration of HDL is also low (Fig. 1 and Table IV), the plasma HDL reservoir of apoC available for transfer to

TABLE V

Composition of the Lipid Moieties of Normal and CTX $\mathrm{HDL}_{3}$

\begin{tabular}{lccc}
\hline \multicolumn{1}{c}{ Component } & CTX & Normal & Literature \\
\hline Phospholipid* & $45.4 \pm 1.9$ & $49.7 \pm 1.3$ & $40.9-51.1(29-31)$ \\
Triglyceride* & $13.8 \pm 1.8$ & $2.2 \pm 0.8$ & $4.5-6.5(29-31)$ \\
Cholesterol & & & \\
Free* & $5.8 \pm 0.9$ & $5.9 \pm 0.8$ & $4.6,5.6(29)$ \\
Esterified* & $15.9 \pm 1.1$ & $22.0 \pm 1.2$ & $18.7,20.1(29)$ \\
Cholesteryl esters & & & \\
Total* & $26.9 \pm 1.8$ & $37.2 \pm 1.5$ & \\
$16: 0 \ddagger$ & 16.6 & 11.0 & $10.7-11.6(31,32)$ \\
$18: 1 \ddagger$ & 25.0 & 17.0 & $18.9-23.6(31,32)$ \\
$18: 2 \ddagger$ & 40.0 & 55.9 & $52.2-57.1(31-33)$ \\
$20.4 \ddagger$ & 11.6 & 9.0 & $5.5-9.9(31-33)$ \\
$16: 1 \ddagger$ & & & $1.7-3.2(31,32)$ \\
$18: 0 \ddagger$ & & & $0.9,1.3(32)$ \\
$20.0 \ddagger$ & & & $0.5,0.8(32)$ \\
\hline
\end{tabular}

* Percent by weight of total lipids. Values are the means \pm SD for 4 CTX patients and 10 normal subjects.

\$ Percent by weight of total cholesteryl esters. Values are for CTX patient W.H. and a normal male. Literature values are for HDL. 


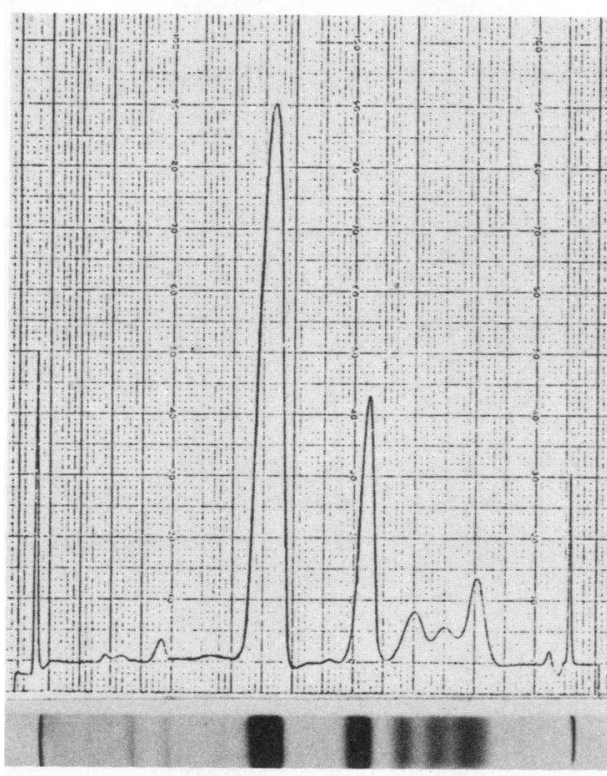

A I AII $C^{\prime} S$
CTX apoHDL 2

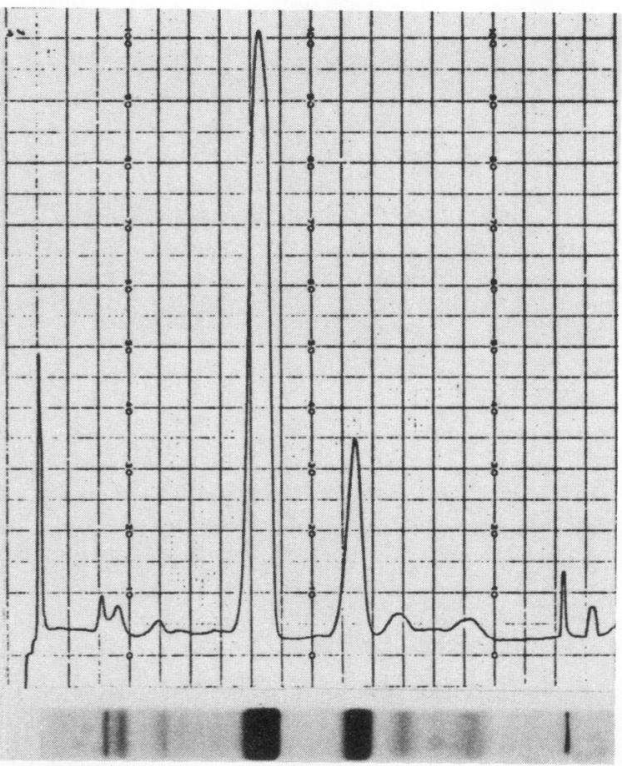

AI AII $C^{\prime} S$

FIGURE 3 Densitometric scans of SDS-polyacrylamide gel electrdphihoretic patterns of apoHDL 2 of normal and CTX subjects.

nascent VLDL is low. However, the VLDL of CTX patients was not deficient in apoE or apoC as determined from the electrophoretic patterns (not shown). Electrophoresis of CTX apoHDL 2 in $4 \%$ SDS gels showed no detectable apoB (pattern not shown).

Isoelectric focusing patterns of CTX apoHDL 2 and apoHDL $\mathrm{H}_{3}$ confirmed the observations from SDS-gel electrophoresis and indicated that a minor form of apoAI $\left(\mathrm{AI}_{\mathrm{x}}\right.$ in Fig. 4) was relatively enriched in all the patients' HDL as compared to normal, fasting HDL. ApoAI $_{x}$ accounted for $\sim 14 \%$ of the total apoAI in CTX apoHDL $\mathrm{H}_{3}$ and $9 \%$ of the total apoHDL $\mathrm{H}_{3}$, according to the densitometric scans (Table VI). In normal HDL, apoAI $\mathrm{I}_{\mathbf{x}}$ ranges from an undetectable amount to about $3 \%$ of the total protein. The densitometric scans of the isoelectric focusing gel patterns also indicated that the average ratio of total apoAI $\left(\mathrm{AI}_{\mathbf{x}}+\mathrm{AI}\right)$ to apoAII in CTX apoHDL 2 and apoHDL $\mathrm{H}_{3}$, respectively, was 4.0 and 3.6. In samples from the control group in this study, the corresponding ratios of the peak areas for total apoAI and apoAII were 3.1 and 2.7, respectively.

ApoAI $_{x}$ was identified as a form of apoAI by the amino acid composition of the proteins eluted from the gels after isoelectric focusing of $300 \mu \mathrm{g}$ apo HDL/gel (Table VII). These analyses also indicated that the bands containing the major forms of apoAI were not significantly contaminated with other apolipoproteins, e.g., apoE, since the composition corresponded closely to that expected for pure apoAI.

\section{DISCUSSION}

Results of this investigation indicate abnormal HDL composition to be a general feature of CTX and that abnormal plasma lipoprotein profiles with low concentrations of LDL and/or HDL are frequent. Particle size and density of the CTX HDL were normal. Thus the total number of HDL particles in CTX plasma, estimated from the analytical ultracentrifugation data (Table IV) are somewhat reduced ( $~ 30 \%$ on the average in males and less in females, in whom the $\mathrm{HDL}_{2}$ are disproportionately low relative to $\mathrm{HDL}_{3}$ ), but not to the extent suggested by the very low HDL-cholesterol (Table II). These data indicate that CTX HDL transport much less cholesterol per lipoprotein particle than normal.

The possible relationship of these abnormalities to the accumulation of cholesterol and cholestanol in extrahepatic tissues of CTX subjects is of some interest because lipoproteins are the transport system for sterol influx and efflux of cells. Cholestanol seems not to be distinguishable from cholesterol in transport, except in the CTX subject's brain, xanthomas, and bile, where cholestanol can account for $10-40 \%$ of total sterols (34, 35 ). In most other cases, red blood cells, and plasma, the proportions of cholestanol to cholesterol (about 1-3\%) are very similar (34). Excess deposition (influx) and/or reduced capacity for removal (efflux) could cause the accumulation in tissue. Increased influx implies 


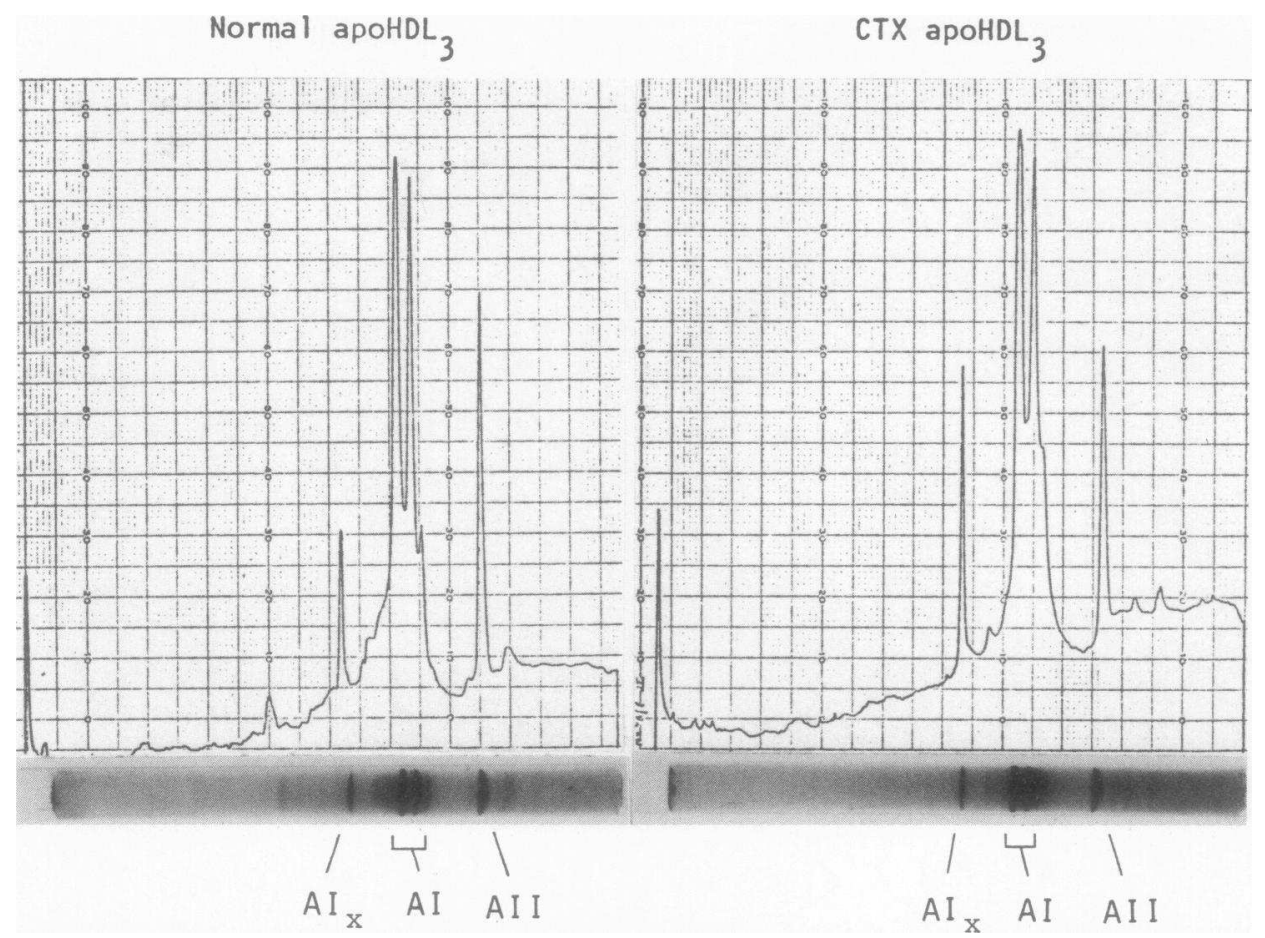

FIGURE 4 Densitometric scans of polyacrylamide gel isoelectric focusing patterns of apoHDL $\mathrm{L}_{3}$ of normal and CTX subjects. The pH range is 4 (at the extreme right of each pattern) to 8 .

elevated plasma LDL (not low LDL as in CTX) and/or increased affinity for tissues. Decreased efflux and/or increased influx could be directly related to the HDL, if

TABLE VI

Apolipoprotein Composition of $\mathrm{HDL}_{2}$ and $\mathrm{HDL}_{3}$ from CTX Patients and Control Subjects*

\begin{tabular}{lcccc}
\hline & \multicolumn{4}{c}{ Total apolipoprotein } \\
\cline { 2 - 5 } Lipoprotein & AI $_{\mathbf{x}}$ & AI & AII & $\begin{array}{c}\text { Minor } \\
\text { components }\end{array}$ \\
\hline HDL $_{2}$ & & \multicolumn{3}{c}{} \\
Controls (3) & $2 \pm 1$ & $66 \pm 4$ & $22 \pm 2$ & $10 \pm 2$ \\
Patients (6) & $7 \pm 1.5$ & $64 \pm 5$ & $18 \pm 2$ & $10 \pm 2$ \\
HDL & & & & \\
Controls (3) & $3 \pm 1$ & $65 \pm 5$ & $25 \pm 2$ & $7 \pm 1$ \\
Patients (6) & $9 \pm 2$ & $62 \pm 7$ & $20 \pm 2$ & $9 \pm 2$ \\
\hline
\end{tabular}

* After polyacrylamide-gel isoelectric focusing of HDL apolipoproteins, gels were scanned densitometrically and the area of each band was expressed as a percentage of total area of the apolipoproteins. Numbers are mean values \pm SD.

† Includes apoC-II, apoC-III, apoD, apoE, and unidentified bands.

Numbers in parentheses are numbers of subjects in the group. Only $30 \%$ of the control subjects had a measurable amount of an apolipoprotein with the same mobility as $\operatorname{apoAI}_{\mathbf{x}}$ on isoelectric focusing. These individuals ( 2 males and 1 female) were selected for this table. The patient group included 3 males and 3 females. major functions of the HDL are the transport of cholesterol from peripheral tissues to the liver (10) and/or the control of LDL-sterol uptake by tissues by modulating LDL binding to membrane receptor sites and transendothelial transport (7-9).

The capacity of the HDL to accept sterols could be diminished by the abnormal composition of CTX HDL or, conversely, defective transfer of cholesterol across the cell membrane could result in abnormal HDL composition. The high ratio of cholesterol to cholesteryl esters, the low content of unesterified cholesterol, and the altered proportion of apolipoproteins AI and AII may diminish the capacity of the HDL of CTX patients to accept unesterified sterols. Esterification of cholesterol and/or the transfer of the lipids among lipoproteins also may be defective. Net transfer of unesterified cholesterol from erythrocytes (and very possibly other cells) to plasma depends on the free cholesterol to phospholipid ratios in cells and plasma lipoproteins and the transfer to plasma is driven by lecithin:cholesterol acyltransferase (36), which converts cholesterol of plasma HDL to cholesteryl esters. Furthermore, the phospholipid complexes of apoAI are less effective than the complexes of apoAII, apoCI, or apoCIII in releasing cellular sterol from Landschütz ascites cells (37). The abnormalities in composition of the HDL of CTX subjects, particularly the relative abundance of apoAI and free cholesterol, should favor the action of lecithin:cholesterol acyl- 
TABLE VII

Amino Acid Composition of Apolipoproteins Isolated* from HDL of CTX Patients

\begin{tabular}{|c|c|c|c|c|c|}
\hline & $\mathbf{A} \mathbf{I}_{\mathbf{x}}$ & $\mathbf{A \mathbf { I } _ { 1 }}$ & $\mathbf{A I}_{\mathbf{2}}$ & $\mathbf{A I}_{3}$ & AII \\
\hline & \multicolumn{5}{|c|}{$\mathrm{mol} / \mathrm{l}, 000 \mathrm{~mol}$} \\
\hline Lys & 78 & 79 & 78 & 80 & 120 \\
\hline His & 19 & 19 & 19 & 18 & 0 \\
\hline Arg & 62 & 63 & 64 & 58 & 0 \\
\hline Asp & 87 & 92 & 93 & 90 & 40 \\
\hline Thr & 38 & 39 & 40 & 39 & 78 \\
\hline Ser & 64 & 62 & 59 & 63 & 80 \\
\hline Glu & 189 & 192 & 190 & 188 & 208 \\
\hline Pro & 38 & 40 & 40 & 41 & 54 \\
\hline Gly & 44 & 39 & 41 & 43 & 43 \\
\hline Ala & 75 & 76 & 78 & 77 & 68 \\
\hline $1 / 2$ Cys & 0 & 0 & 0 & 0 & 14 \\
\hline Val & 50 & 48 & 51 & 52 & 75 \\
\hline Met & 13 & 12 & 12 & 12 & 13 \\
\hline Ile & 0 & 0 & 0 & 0 & 14 \\
\hline Leu & 160 & 159 & 152 & 158 & 104 \\
\hline Tyr & 26 & 25 & 27 & 27 & 47 \\
\hline Phe & 23 & 21 & 24 & 24 & 48 \\
\hline
\end{tabular}

* By preparative isolectric focusing.

transferase (38). However, the variant apoAI $\mathrm{I}_{\mathrm{x}}$ may not be an effective cofactor for the reaction and it might even be inhibitory. ApoAI $\mathrm{I}_{\mathbf{x}}$ (not characterized previously) seems to be normal but minor form of apoAI that is considerably enriched in CTX HDL. The effect of increased cholestanol on the properties and metabolism of CTX HDL is not known. Perturbations are possible even though cholestanol accounts for only a small fraction of the total sterols.

Abnormalities in HDL concentration and apolipoprotein composition, particularly the relative abundance of apoAI $\mathrm{X}_{\mathrm{X}}$ may derive in part from the known CTX abnormalities in synthesis and composition of bile acids (5) and morphology of the liver cells (39). Liver functions including synthesis and secretion of nascent lipoproteins may be coupled to the flux of the bile acid pool though the liver, which is deficient in CTX.

\section{ACKNOWLEDGMENTS}

The work of Dr. Salen, Dr. Chen, Dr. Tint, and Dr. Shefer was supported by U.S. Public Health Service grants AM18707, HL-17818 and AM-26756. The work of Dr. Forte, Dr. Lindgren, and Dr. Shore was supported by grants HL-18574 and HL-23747, and was carried out under the auspices of the U.S. Department of Energy by the Lawrence Livermore and Berkeley Laboratories under contract number W-7405ENG-48.

\section{REFERENCES}

1. Salen, G. 1971. Cholestanol deposition in cerebrotendinous xanthomatosis: a possible mechanism. Ann. Intern. Med. 75: 843-851.
2. Menkes, J. H., J. R. Schimschock, and P. C. Swanson. 1968. Cerebrotendinous xanthomatosis: the storage of cholestanol within the nervous system. Arch. Neurol. 19: 47-53.

3. Philippant, M., and L. Van Bugaert. 1969. Cholestanolosis (cerebrotendinous xanthomatosis): a follow-up study on the original family. Arch. Neurol. 21: 603-610.

4. Setoguchi, T., G. Salen, G. S. Tint, and E. H. Mosbach. 1974. A biochemical abnormality in cerebrotendinous xanthomatosis. Impairment of bile acid biosynthesis associated with incomplete degradation of the cholesterol side chain. J. Clin. Invest. 53: 1393-1401.

5. Salen, G., S. Shefer, F. W. Cheng, B. Dayal, A. K. Batta, and G. S. Tint. 1979 Cholic acid biosynthesis: the enzymatic defect in cerebrotendinous xanthomatosis. J. Clin. Invest. 63: 38-44.

6. Gordon, T., W. P. Castelli, M. C. Hjortland, W. B. Kannel, and T. R. Dawber. 1977. High density lipoprotein as a protective factor against coronary heart disease. The Framingham Study. Am. J. Med. 62: 707-714.

7. Stein, O., and Y. Stein, 1976. High density lipoproteins reduce uptake of low density lipoproteins by human endothelial cells in culture. Biochim. Biophys. Acta. 431: 363-368.

8. Carew, T. E., T. Koschinsky, S. B. Hayes, and D. Steinberg. 1976. A mechanism by which high-density lipoproteins may slow the atherogenic process. Lancet I: 13151317.

9. Angel, A., M. A. D'Costa, and R. Yuen. 1979. Low density lipoprotein binding, internalization, and degradation in human adipose cells. Can. J. Biochem. 57: 578-587.

10. Glomset, J. A. 1972. Plasma lecithin: cholesterol acyltransferase. In Blood Lipids and Lipoproteins. G. J. Nelson, editor. John Wiley \& Sons, Inc., New York. 745-788.

11. Manual of Laboratory Operations, Lipid Research Clinics Program. Lipid and Lipoprotein Analysis. 1975. Department of Health, Education, and Welfare, National Institutes of Health, U. S. Government Printing Office, Washington, D. C. 1: 75-628.

12. Allain, C. C., L. S. Poon, C. S. G. Chan, W. Richmond, and P. C. Fu. 1974. Enzymatic determination of total serum cholesterol. Clin. Chem. 20: 470-475.

13. Ewing, A. M., N. K. Freeman, and F. T. Lindgren. 1965. The analysis of human serum lipoprotein distributions. In Adv. Lipid Res., R. Paoletti and D. Kritchevsky, editors. Academic Press, Inc., New York. 3: 26-61.

14. Lindgren, F. T. 1974. Serum lipoproteins: isolation and analysis with the preparative and analytical ultracentrifuge. In Fundamental of Lipid Chemistry. R. M. Burton, and F. C. Guerra, editors. Bi-Science Publications Division, Webster Groves, Mo. 475-510.

15. Shore, B. 1957. C- and N-terminal amino acids of human serum lipoproteins. Arch. Biochem. Biophys. 71: 1-10.

16. Lowry, O. H., N. J. Rosebrough, A. L. Farr, and R. J. Randall. 1951. Protein measurement with the Folin phenol reagent. J. Biol. Chem. 193: 267-275.

17. Chen, P. S. Jr., T. Y. Toribara, and H. Warner. 1956. Microdetermination of phosphorus. Anal. Chem. 28: 1756-1758.

18. Nelson, G. J. Quantitative analysis of blood lipids. In Blood Lipids and Lipoproteins. G. J. Nelson, editor. John Wiley \& Sons, Inc., New York. 25-73.

19. Lindgren, F. T., L. C. Jensen, and F. T. Hatch. 1972. The isolation and quantitative analysis of serum lipoproteins. In Blood Lipids and Lipoproteins. G. J. Nelson, editor. John Wiley \& Sons, Inc., New York. 181-274.

20. Anderson, D. W., A. V. Nichols, T. M. Forte, and F. T. 
Lindgren. 1977. Particle distribution of human serum high density lipoproteins. Biochim. Biophys. Acta. 493: 55-68.

21. Forte, T., K. Norum, J. A. Glomset, and A. V. Nichols. 1971. Plasma lipoproteins in familial lecithin: cholesterol acyltransferase deficiency: structure of low and high density lipoproteins as revealed by electron microscopy. J. Clin. Invest. 50: 1141-1148.

22. Sipos, J. C., and R. G. Ackman. 1978. Automated and rapid quantitative analysis of lipids with chromarods. J. Chromatogr. Sci. 16: 443-447.

23. Duncan, I. W., P. H. Culbreth, and C. A. Burtis. 1979. Determination of free, total, and esterified cholesterol by high-performance liquid chromatography.J. Chromatogr. 162: 281-292.

24. Liu, T.-Y., and Y. H. Chang. 1972. Hydrolysis of proteins with $\rho$-toluenesulfonic acid. J. Biol. Chem. 246: 28422848.

25. Shore, V. G., R. E. Garcia, A. L. Penn, and B. W. Shore. 1980. Polyacrylamide gel electrophoresis and isoelectric focusing of plasma apolipoproteins. In Chemical Rubler Co. Handbook of Electrophoresis. L. A. Lewis and J. J. Opplt, editors. Chemical Rubler Co. Press, Boca Raton, Fla. 1: 103-125.

26. Salen, G., and S. M. Grundy. 1973. The metabolism of cholestanol, cholesterol, and bile acids in cerebrotendinous xanthomatosis. J. Clin. Invest. 52: 2822-2835.

27. Lindgren, F. T., G. L. Adamson, L. C. Jensen and P. D. Wood. 1975. Lipid and lipoprotein measurements in a normal adult American population. Lipids. 10: 750-756.

28. Frederickson, D. S., R. I. Levy, and F. T. Lindgren. 1967. A comparison of heritable abnormal lipoprotein patterns as defined by two different techniques. J. Clin. Invest. 47: 2446-2457.

29. Skipski, V. P. 1972. Lipid composition of lipoproteins in normal and diseased states. In Blood Lipids and Lipoproteins. G. J. Nelson, editor. John Wiley \& Sons, Inc., New York. 472-583.
30. Scanu, A., and J. L. Granada. 1966. Effects of ultracentrifugation on the human serum high density $(1.063$ $<\rho<1.21 \mathrm{~g} / \mathrm{ml}$ ) lipoprotein. Biochemistry. 5: 446-455.

31. Scanu, A. M. 1973. The structure of human serum low- and high-density lipoproteins. In Atherogenesis Initiating Factors. Ciba Foundation Symposium No. 12. Elsevier North-Holland, Inc. 223-246.

32. Goodman, D. S., and T. Shiratori. 1964. Fatty acid composition of human plasma lipoprotein fractions. J. Lipid Res. 5: 307-313.

33. Akanuma, Y., and J. Glomset. 1968. In vitro incorporation of cholesterol- ${ }^{14} \mathrm{C}$ into very low density lipoprotein cholesteryl esters. J. Lipid. Res. 9: 620-626.

34. Salen, G., and E. H. Mosbach. 1976. The metabolism of sterols and bile acids in cerebrotendinous xanthomatosis. In The Bile Acids. P. P. Nair and D. Kritchevsky, editors. Plenum Publishing Corporation, New York. 3: 115-153.

35. Bhattacharyya, A. K., and W. E. Connor. 1978. Familial diseases with storage of sterols other than cholesterol. In The Metabolic Basis of Inherited Disease, 4th edition. J. B. Stanbury, J. B. Wyngaarden, and D. S. Fredrickson, editors. McGraw-Hill Book Co., Inc., New York. 656-669.

36. Lange, Y., and J. S. D'Alessandro. 1977. Characterization of mechanisms for transfer of cholesterol between human erythrocytes and plasma. Biochemistry. 16: 43394343.

37. Jackson, R. L., A. M. Gotto, O. Stein, and Y. Stein. 1975. A comparative study on the removal of cellular lipids from Landschütz ascites cells by human plasma apolipoproteins. J. Biol. Chem. 250: 7204-7209.

38. Fielding, C. J., V. G. Shore, and P. E. Fielding. 1972. Lecithin: cholesterol acyltransferase: effects of substrate composition upon enzyme activity. Biochim. Biophys. Acta. 270: 513-518.

39. Salen, G., S. Shefer, and F. G. Zaki. 1978. Intrahepatic pigment and crystal forms in patients with cerebrotendinous xanthomatosis (CTX). Gastroenterology. 74: 82-89. 